\title{
A erótica vanguardista de Oliverio Girondo
}

\section{La erótica vanguardista de Oliverio Girondo}

\section{BRUNO VERNECK}

\section{RESUMO}

O presente texto tem por objetivo discutir o poema "Biarritz" do escritor argentino Oliverio Girondo, pensando sua forma a partir das premissas vanguardistas amplamente difundidas na América-Latina nas primeiras décadas do século XX. Para tal, procura analisar a poética do fragmento, presente no trabalho do escritor argentino, como um traço das diversas modalidades e disciplinas em que as vanguardas históricas se manifestaram. Nos 20 poemas para ser leídos en el tranvía, o trabalho com o fragmentário possibilita a construção das imagens do erótico que permeiam o livro. A presente leitura busca compreender de que modo, ao construir o olhar do eulírico nestes poemas, Girondo articula a experiência da modernidade à discreta obsessão pelos corpos femininos. Por fim, tendo em vista o forte caráter interdisciplinar das vanguardas históricas, o texto se debruça sobre os desenhos do autor que ilustram a obra para buscar continuidades com relação à construção imagética de seus poemas.

PALAVRAS CHAVE: Poesia Argentina; Erotismo; Vanguardas Históricas; Modernidade Latino-Americana.

\section{RESUMEN}

El presente texto tiene por objetivo discutir el poema "Biarritz" del escritor argentino Oliverio Girondo, pensando su forma a partir de las premisas vanguardistas ampliamente difundidas en América Latina en las primeras décadas del siglo XX. Para ello, busca analizar la poética del fragmento, presente en el trabajo del escritor argentino, como un rasgo de las diversas modalidades y disciplinas en que las vanguardias históricas se manifestaron. En los 20 poemas para ser leídos en el tranvía, el trabajo con el fragmentario posibilita la construcción de las imágenes del erótico que permean el libro. La presente lectura busca comprender de qué modo, al construir la mirada del yo-lírico en estos poemas, Girondo articula la experiencia de la modernidad a la discreta obsesión por los cuerpos femeninos. Por último, teniendo en cuenta el fuerte carácter interdisciplinario de las vanguardias históricas, el texto se centra en los dibujos del autor que ilustran la obra para buscar continuidades con relación a la construcción imagética de sus poemas.

PALABRAS CLAVE: Poesía Argentina; Erotismo; Vanguardias Históricas; Modernidad Latinoamericana.

\section{A DESMESURA VANGUARDISTA}

A cultura europeia ardia nas primeiras décadas do século XX. Decididos a demolir a "instituição arte", os intelectuais do período produziam, teorizavam e debatiam as possibilidades de vanguarda em seus respectivos "ismos". Estando na linha de frente da mudança, munidos de artilharia para estraçalhar o status quo, o ataque ao belo, ao harmônico e à arte contemplativa entravam na ordem do dia. Não tardou para que a ebulição vanguardista atravessasse o atlântico e chegasse às terras americanas.

O crítico brasileiro Antonio Candido, no texto “Literatura e Cultura 1900-1945” de seu livro 
clássico Literatura e Sociedade, afirma que: "As terríveis ousadias de um Picasso, um Brancusi, um Max Jacob, um Tristan Tzara, eram, no fundo, mais coerentes com a nossa herança cultural do que com a deles" (CANDIDO, 2014, p. 128). Se na pesquisa de muitos artistas do período a reunião de elementos primitivos (de matriz africana ou indígena) com os avatares europeus resultaria em uma peça legitimamente vanguardista, no caso latino-americano bastaria perambular pelas ruas para deparar-se com o mesmo efeito, dada a mescla cultural que nos constitui.

Como verifica Müller-Bergh, "los jóvenes de la vanguardia (...) de todo em continente americano oscilan entre los polos del primitivismo y un esteticismo ultramoderno (...)” (1982, p. 165). A busca pelo primitivo, que agora é "fonte de beleza e não mais empecilho à elaboração da cultura" (CANDIDO, 2014, p. 127) corre em paralelo ao fascínio pela cosmópolis viva e multifacetada. É esta Cidade-Eros, em que nada se conserva, transmutando-se em novo a cada instante, que encontramos nos Veinte poemas para ser leídos en el tranvía de Oliverio Girondo.

A poesia de Girondo enfrenta a cidade moderna. Diferente dos predecessores modernistas (reunindo elementos das poéticas simbolistas e parnasianas) que buscavam refugiar-se para preservar a "sensibilidade ameaçada" ${ }^{1}$, abstraindo dos cenários que marcaram a sociedade de massas, em gesto oposto ao que encontramos nas poéticas do início do século XX. Aqui estão confrontadas as "duas tradições da modernidade (...) a estética da autonomia, cujo auge foi alcançado com o esteticismo do final do século XIX, e o impulso vanguardista de superação da autonomia e recondução da arte para a prática da vida” (SIMMON, 2008, Orelha do livro). Se a poesia de Baudelaire bradava: "Horloge! dieu sinistre, effrayant, impassible", onde a subjetividade se revolta contra o relógio, símbolo por excelência desses assombrosos tempos modernos, encontraremos na poesia de Oswald de Andrade o mesmo objeto em chave inofensiva, marcando o tempo das coisas, que "Vão e vêm / Não em vão".

O tom porvenirista, como chamou Saúl Yurkievich $(1995,89-98)$, que marca a poesia de Oliverio Girondo tem raízes profundas na sociedade Argentina da passagem do século XIX para o XX. A virada do século marca o desenvolvimento e a modernização os centros urbanos latino-americanos, iniciados no século XIX, à medida que as economias das jovens nações ao sul do Rio Grande se desenvolviam. O acenar para a industrialização e um amplo mercado de exportação ampliaram a experiência do moderno nestas cidades. Buenos Aires era um dos principais catalizadores dessa modernização.

Portanto, cantar a cidade nos anos de 1920 é cantar com fervor o moderno fascinante e a prosperidade econômica. Exemplo objetivo de tal movimento é o poema "Aperitivo" do

\footnotetext{
1 Aqui me refiro ao livro de Graciela Montaldo, La sensibilidade amenazada. Fin de siglo y modernismo, em que o movimento do modernismo de tensão com o presente está amplamente debatido.
} 
brasileiro Oswald de Andrade:

A felicidade anda a pé

Na Praça Antônio Prado

São 10 horas azuis

O café vai alto como a manhã de arranha-céus

Cigarros Tietê

Automóveis

A cidade sem mitos ${ }^{2}$

Nestes flashes do olhar, o eu-lírico passeia em um dos cartões postais paulistanos: a Praça Antônio Prado. Há um paralelo entre o café e os arranha-céus a partir da metáfora do "alto", estabelecendo assim, uma ponte entre a modernidade experienciada e as bases econômicas que a sustentam. O tom celebrativo do poema marca o prazer de contemplar esta cidade pulsante, clara (sem os mitos que antes acinzentavam as representações) e que inaugura um novo horizonte de possibilidades para a arte e para a vida - elementos que se equivalem no interior da obra vanguardista ${ }^{3}$. Excitação muito similar pode ser encontrada na obra de Oliverio Girondo.

\begin{abstract}
"MARTÍN FIERRO", se encuentra, por eso, más a gusto, en un transatlántico moderno que en un palacio renacentista, y sostiene que un buen Hispano-Suiza es una OBRA DE ARTE muchísimo más perfecta que una silla de manos de la época de Luis XV. (GIRONDO, 1924, p. 1)
\end{abstract}

No fragmento supracitado do jubiloso Manifesto Martín Fierro, de 1924, publicado na revista de mesmo nome, está expressa a "modernolatria" do martinfierrismo, propiciada por seu caráter altamente cosmopolita, reiterada em franca oposição ao modernismo:

Acentuar y generalizar, a las demás manifestaciones intelectuales, el movimiento de independencia iniciado, en el idioma, por Rubén Darío, no significa, empero, finjamos desconocer que todas las mañanas nos servimos de un dentífrico sueco, de unas tohallas de Francia y de un jabón inglés. (GIRONDO, 1924, p. 2)

2 Tanto o verso do poema "Relógio" quanto o poema "Aperitivo" são extraídos da seguinte edição ANDRADE, Oswald de. Obras completas. Rio de Janeiro: Civilização Brasileira, 1971. Respectivamente nas páginas 45 e 126.

3 Este tema já foi amplamente estudado pela crítica, tendo no texto "A carroça, o bonde e o poeta modernista", de Roberto Schwarz (1989), sua mais clara exposição. Para um olhar no amplo contexto latino-americano, Cf. OSORIO, Nelson (1982). 
Aqui está o movimento essencial do olhar empreendido pelos intelectuais ao redor da Revista Martín Fierro: reconhecer a autonomia intelectual americana, com seus rasgos diferenciais (marcado desde o nome pela referência ao “poema nacional” de José Hernández), mas não recusar o traço cosmopolita que os constitui. É o que vai formular Borges, anos mais tarde, em 1951, ao falar da relação dos escritores argentinos com a tradição: "Creo que nuestra tradición es toda la cultura occidental, y creo también que tenemos derecho a esa tradición" (BORGES, 1974, p. 272).

“Os testemunhos são unânimes em enfatizar o caráter revolucionário do grupo”, aponta Jorge Schwartz (2008, p. 91). A geração martinfierrista empreendeu não apenas uma renovação estética, com seu caráter altamente interdisciplinar, mas também possibilitou uma importante mudança no mercado editorial da época. Era prática comum, até então, que os autores custeassem as suas obras editadas, prática que é abolida a partir do trabalho destes escritores, assinalando "um momento único de consciência cultural coletiva e um divisor de águas na cultura argentina". (SCHWARTZ, 2008, p. 92).

Principal nome desta geração é, sem dúvidas, Oliverio Girondo. Redator do manifesto acima citado, o escritor também se aventura nestas novas formas de poesia. Seus 20 poemas para ser leídos en él tranvía, publicados em 1922, podem ser lidos a luz do gesto vanguardista. No livro, encontramos as marcas evocadas pelo manifesto: o cosmopolitismo, o fascínio da modernidade, a interdisciplinaridade (expressa nos desenhos do próprio autor que ilustram alguns poemas do livro), empreendendo múltiplas viagens no correr de páginas do livro.

Tais viagens supõem um sentido bifronte: passando as páginas dos 20 poemas vamos de Buenos Aires ao Rio de Janeiro, em seguida para Sevilha, e depois Biarritz... O eu-lírico é um viajante cosmopolita que registra, com olhos tais quais uma máquina fotográfica, este mundo exalando modernidade. O gesto viajante também sinaliza um procedimento formal: a imagem, central para a concepção dos poemas, é trabalha sob deslizamentos que exploram as possibilidades da composição fragmentária.

O fragmento, trabalhado pelas diversas artes da vanguarda, é central para a composição dos poemas do livro de Oliverio Girondo. Os motivos do erótico, essenciais ao retratar os corpos femininos, são filtrados pela dialética fatal do fragmento. Interessa discutir no presente trabalho de que maneira os temas do erótico encontram nos 20 poemas um tratamento vanguardista, ampliando e redistribuindo o visível e instaurando um diálogo entre a lírica e os desenhos do poeta que ilustram o livro.

\section{TRAMAS DO VISÍVEL: UMA ERÓTICA VANGUARDISTA}

Não há nada maior que um bando de pescadores, cheio de velhos e ingênuos costumes, sentados à beira do mar. Não há nada maior que uma cidade que parece ter a nobre função de pensar para toda a humanidade e propor ao mundo as novidades, muitas vezes difíceis e duvidáveis, que a civilização cobra. Não há nada menor, mais mesquinho e mais ridículo do que uma Paris falseada. As cidades que o mar banha deveriam preciosamente conservar a 
fisionomia que esta situação lhes dá. O mar é de toda graça, de toda beleza, de toda grandeza. Quando se tem o mar, por que copiar Paris? ${ }^{4}$ (HUGO, 1910, p. 312).

A descrição acima é do francês oitocentista Victor Hugo. Em suas voyages, o poeta visita Biarritz, comuna francesa muito próxima da divisa com Espanha, e encontra nela o espaço do fugere urbem. As belezas estão ligadas ao seu aspecto ilibado, tendo na imagem do oceano um símbolo de purificação próprio de um lugar distante dos valores corruptores da civilização. Porém, nota o escritor o desejo de copiar Paris, de alçar-se para o urbano, vontade que é censurada por esta alma romântica, preocupada em preservar o idílio. Pouco mais de meio século depois, encontramos "Biarritz", um dos 20 poemas para ser leídos en el tranvía.

1 El casino sorbe las últimas gotas de crepúsculo.

2 Automóviles afónicos. Escaparates constelados de estrellas falsas. Mujeres que van a perder sus sonrisas al bacarás.

Diferente da admirável simplicidade vislumbrada por Hugo em 1843, aqui Biarritz é definitivamente um espaço moderno. A máquina ("automóviles afónicos"), o capital ("de tanto ver passar dinero") e o luxo ("collares de perlas") armam o cenário em que este eu-lírico parece pasmado enquanto contempla os elementos girando ao seu redor. Neste espaço anti-ilídico, já tomado pelos signos da modernização, o eu-lírico está assoberbado em um cassino local. A cada verso somos deslocados e apresentados aos personagens e objetos que desfilam no luxuoso cenário.

Fazendo a viravolta na relação sujeito-objeto, o primeiro verso verte o tempo em água, trazendo-o do campo imaterial para uma materialidade visual. Tal procedimento, que vai se repetir no decorrer do poema, consiste em conferir vida aos objetos inanimados e mostrar como, no cassino, são eles que motivam as ações humanas.

Estamos entre o fim da noite e início da manhã. O segundo verso nos transporta do ambiente exterior para o interior a partir das imagens sucessivas. Do automóvel afônico que transita na rua, passamos para as vitrines que constituem um meio termo, em que as "estrelas falsas" estão para endossar seu objetivo: expor-se ao espaço público/fora, convidando-o para o privado/dentro. É um interstício entre exterior e interior. Já na terceira imagem a entrada no cassino de concretiza e, no verso seguinte, estamos debruçados na mesa de apostas assistindo à derrocada de uma senhora.

3 Con la cara desteñida por el tapete, los "croupiers" ofician, los ojos bizcos de tanto ver pasar dinero.

4 Traduzido, em razão da presente publicação, por Igor Moraes Barros de Azevedo do original francês.

${ }^{5}$ Enumero os versos de modo a facilitar a menção a estes no decorrer da análise. 
O feltro da mesa desbotando os croupiers, assim como ficam vesgos com os movimentos do dinheiro, assim como as pupilas derretendo-se pela magia das cartas, marcam a submissão dos presentes aos objetos que circulam no ambiente. Longe de ser uma sedução inocente, as peças avançam sobre os presentes, tal qual as pérolas que ganham dentes e, de modo vampiresco, se agarram aos pescoços aristocráticos. O uso de exclamativos desponta como explosões imagéticas, intensificando o prazer da experiência visual.

A relação de sedução e submissão aos objetos, está orquestrada pelo cassino antropomorfizado desde o primeiro verso. O modo de entrega da cena é parte da visada irônica do eu-lírico, mostrando uma classe social submetida ao luxo e aos deslindes do vício, promovidos pelo ambiente e reforçados pela animosidade dos objetos.

O ritmo do poema é marcado pelo modo frenético com que as imagens passam pelos olhos do eu-lírico. Lendo, de algum modo, estamos de "ojos bizcos" assim como os croupiers. Somos deslocados especialmente de modo rápido no segundo verso e conduzidos a um banquete de figuras, convidados a conferir seus traços extravagantes.

6 Hay efebos barbilampiños que usan una bragueta en el trasero. Hombres con baberos de porcelana. Un señor con un cuello que terminará por estrangularlo. Unas tetas que saltarán de un momento a otro de un escote, y lo arrollarán todo, como dos enormes bolas de billar.

7 Cuando la puerta se entreabre, entra un pedazo de "Fox-trot".

No sexto verso, quatro imagens se sucedem, como se mimetizassem um virar da cabeças do sujeito lírico. Pela mirada frenética desta subjetividade vemos o transitar alucinado de objetos frente ao sedentarismo prazeroso e encantado de homens e mulheres. Há, no entanto, uma menção ao nome onipresente que é o responsável por conferir alma e dinamizar a cena cantada: "los ojos bizcos de tanto ver pasar dinero". É o dinheiro a mola motriz e o mestre que orquestra o espetáculo do jogo.

Aos olhos destes jogadores, tudo gravita e encarna o dinheiro: ou pela ostentação da fortuna que possuem (colares, babadores de porcelana) ou pela possibilidade de ampliar o que já possuem pelo jogo (cartas, feltro). Os objetos acabam sendo representações materiais do que pulsa por sobre todo o sentido do jogo: enriquecer ou multiplicar o patrimônio, portanto, ganar plata. Não há dúvidas que neste movimento alucinado e invisível que flagra o eu-lírico há um distanciamento irônico com relação às personagens seduzidas pelo luxo, mas, na mesma medida, ele também se embebe nesta agitação feroz.

A ironia está no processo de encantamento com o objeto que alude ao dinheiro (Verso 4) e também nos deslizamentos metonímicos empreendidos no Verso 6. No verso em questão, que 
forma uma espécie de pequeno parágrafo, temos quatro imagens em sequência, cujo procedimento é semelhante. O eu lírico toma um todo neutro, no caso dos corpos masculinos, e o olhar desliza para uma característica particular, o que ocorre de maneira inversamente proporcional com a figura feminina e suas implicações que posteriormente serão comentadas.

Temos efebos, homens e um senhor no início das frases, depois cada um deles recebe, respectivamente, sua característica distintiva: a braguilha no traseiro - referência a homossexualidade -, os babadores de porcelana e o colarinho apontam para o desconforto com as elegantes vestimentas burguesas. A ironia na construção destes tipos masculinos ganha outros matizes na imagem feminina.

Aqui, no lugar de um olhar sobre o todo que desliza para a parte, há um processo inverso, há um olhar direto para um fragmento da figura que adquire totalidade. Neste caso, é no flagrar dos seios fartos que a construção se concretiza. Não há menção a figura completa, apenas esta parte é fixada. É ela o atrativo para o eu-lírico por seu aspecto erótico. É o olhar que basta. $\mathrm{O}$ caráter fragmentário é bastante interessante: não só há o fragmento a partir do deslizamento metonímico, mas há uma espécie de "pedaço de mulher" que a qualquer momento pode cair, desintegrar-se do corpo, dono de uma autonomia já marcada por sua construção: quem era a dama dona dos seios? Nada sabemos, apenas que eram estes fartos, independentes e sedutores.

Las chicas de Flores, se pasean tomadas de los brazos, para transmitirse sus es-tremecimientos, y si alguien las mira en las pupilas, aprietan las piernas, de miedo de que el sexo se les caiga en la vereda.

Neste verso do poema "Exvoto" - que também integra os 20 poemas - temos o mesmo procedimento no que tange ao olhar para o corpo feminino. O fragmento do corpo que condensa a potência erótica é tão poderoso e carregado simbolicamente que ele está, na poesia de Girondo, sempre buscando sua autonomia, querendo deixar de ser parte para adquirir totalidade, desejando romper a relação dialética a que está fatalmente condenado. Também nos desenhos, feitos pelo próprio autor, que ilustram o livro, o caráter fragmentário aparece expresso nas quatro figuras femininas representadas.

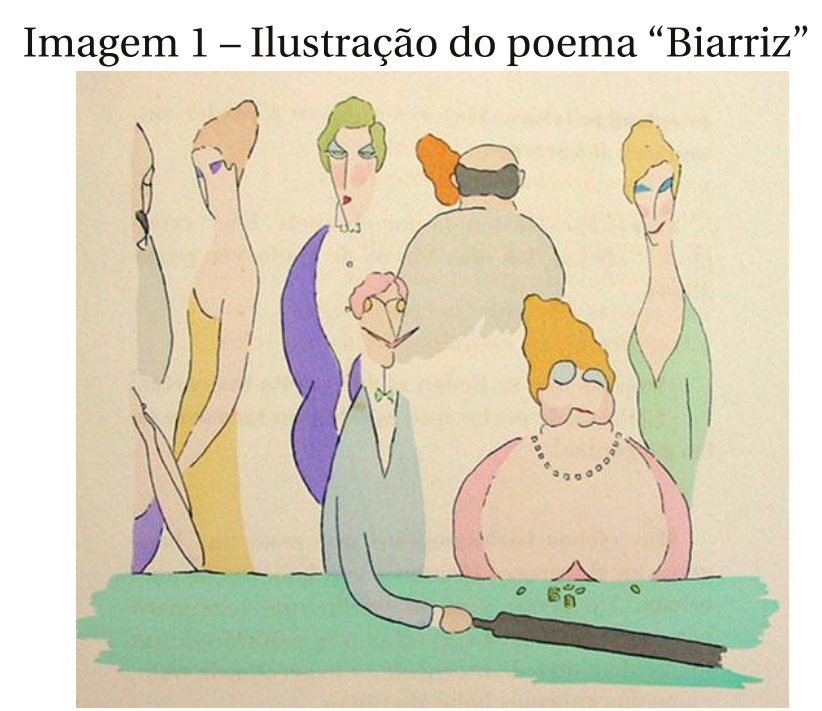


No desenho acima, que ilustra o poema Biarritz, vemos a representação da movimentação no cassino e os decotes avantajados das senhoras que transitam pela cena. A figura de colar, sentada, tem os seios al borde da mesa e que, assim como diz o poema, parecem estar a ponto de pular. O seio também ganha centralidade nos demais desenhos.

\section{Imagem 2 - Ilustração do poema "Plaza"}

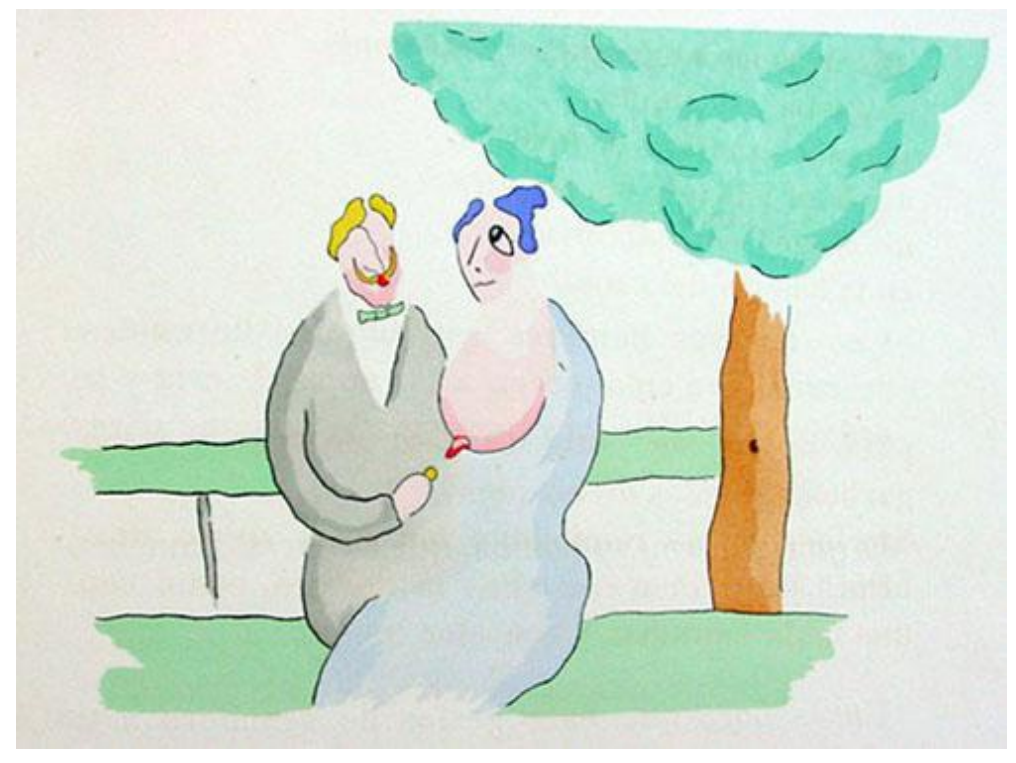

Fonte: 20 poemas para ler no bonde. Edição Brasileira. (GIRONDO, 2014).

Neste outro desenho, que ilustra o poema "Plaza", vemos o seio cheio, com os bicos entumecidos e, voltando ao texto, revela-se o tipo de ordenha que este homem empreende: trata-se de extrair dinheiro que a jovem ganha trabalhando como ama de leite. Novamente os motivos do erótico aparecem ligados as "razões" do dinheiro.

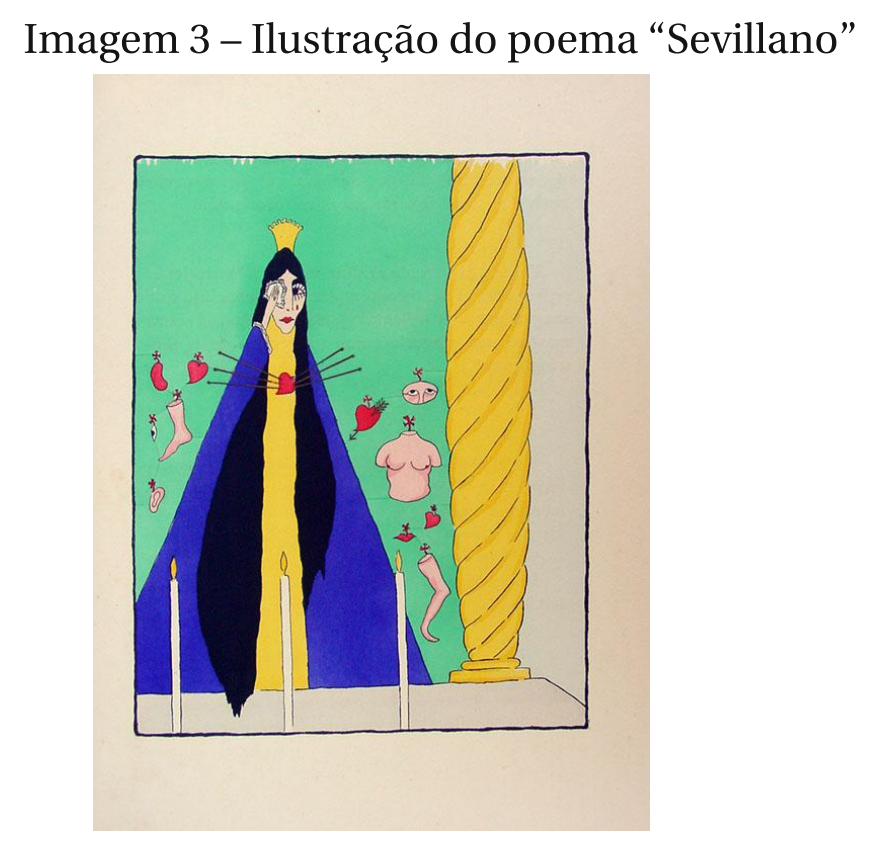


A figura da Virgem, que ilustra o poema "Sevillano", constrói uma visada irônica com relação ao modo santificado com que as jovens beatas descritas no poema se portam. Estas frequentadoras assíduas da igreja não deixam de excitar-se diante da imagem do Cristo crucificado. O corpo feminino coberto pelo pudor religioso é violado pelo desenho, que o tira de dentro das vestes e faz suas partes flutuarem pelo entorno. Desmembrado, posto em claro, o fragmento revela as razões intimas que as máscaras sociais buscam ocultar.

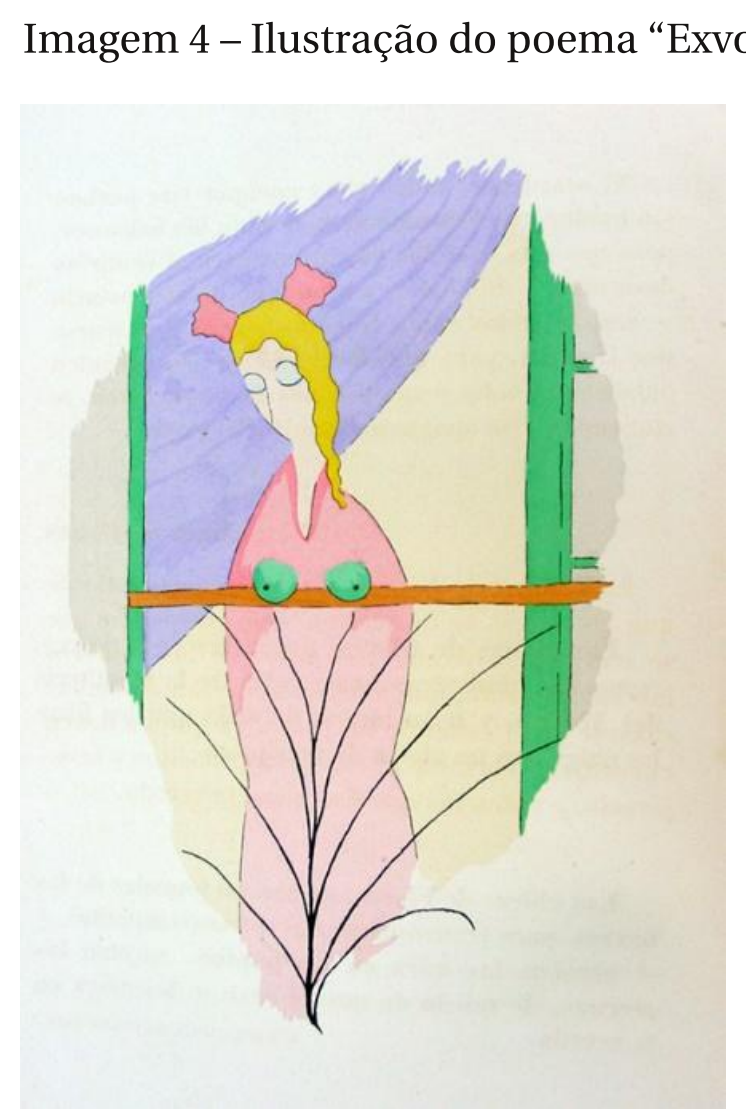

Fonte: 20 poemas para ler no bonde. Edição Brasileira. (GIRONDO, 2014).

Por fim, o desenho que ilustra o antes mencionado poema "Exvoto" fala do jogo de sedução das garotas de Flores, em seu fingido pudor diurno, contrastado com a licença noturna para que os rapazes "les eyaculen palabras al oído". Aqui, o seio aparece não apenas destacado, mas quase como um elemento externo, como se rasgasse as vestes com sua pulsão incontrolável de se revelar. A tensão dos corpos mimetiza a pulsão vanguardista: estão presos em um mundo que exige o ocultamento, mas certas regiões da topografia humana, em que se concentra o desejo de transgredir, não podem suportar as convenções. Eles explodem e se revelam, fugindo do controle racional.

Sigmund Freud em Esquema del psicoanálisis, originalmente de 1938, trata da centralidade do seio para a experiência erótica e suas raízes.

El primer objeto erótico del niño es el pecho materno nutricio; el amor se engendra 
apuntalado en la necesidad de nutrición satisfecha. Por cierto que al comienzo el pecho no es distinguido del cuerpo propio, y cuando tiene que ser divorciado del cuerpo, trasladado hacia «afuera» por la frecuencia con que el niño lo echa de menos, toma consigo, como «objeto», una parte de la investidura libidinal originariamente narcisista. (FREUD, 1991, p. 202).

É o seio, na perspectiva freudiana, este "objeto" primeiro do erótico, que se descola do corpo do sujeito, levado pelo corpo de um outro. A primeira falta. O primeiro fragmento que se descola do corpo. Está aí vislumbrado o abismo entre os seres de que fala George Bataille em $O$ erotismo. "Toda a concretização erótica tem por princípio uma destruição da estrutura do ser fechado que é, no estado normal, um parceiro do jogo" (BATAILLE, 1987, p. 14). Para Bataille, concretizar o erótico é apagar os limites dos seres, aproximar os corpos de modo a unificá-lo, extinguindo a incômoda descontinuidade que sugere a morte. "Do erotismo é possível dizer que ele é a aprovação da vida até na morte.” (BATAILLE, 1987, p. 10). O olhar erótico para o corpo do outro, é o primeiro gesto de aproximação. Nestes poemas de Girondo, em que o seio feminino catalisa o olhar - de modo a extinguir a unidade da figura feminina - constitui-se uma mirada para este objeto-primeiro do erótico perdido. Nestes seios fartos que povoam poemas e desenhos, a falta do sujeito é preenchida no observar do excesso do outro.

Esta representação fragmentária do corpo é estudada por Eliane Robert Moraes no livro $O$ corpo impossivvel. O panorama feito pela autora vai do fim do século XVIII até a segunda metade do século $\mathrm{XX}$, mostrando que a fragmentação teve muita força nas vanguardas históricas:

\footnotetext{
Diante de um mundo em pedaços e do amontado de ruínas que se tornara a história, para utilizarmos os termos de Walter Benjamin, só restava ao artista capturar os fragmentos e as instáveis sensações do presente. A arte moderna respondeu à trama do caos através de formas fraturas, estrutura parodísticas, justaposições inesperadas, registros de fluxos de consciência e da atmosfera de ambiguidade e ironia trágica que caracterizam tantas obras do período. (MORAES, 2002, p. 57)
}

O gosto pelo fragmento é, segundo a autora, marca indelével deste momento. Não à toa o poema de Girondo, fruto deste contexto, se encerra com o verso que fala de um "pedazo de fox-trot", trazendo a experiência de ouvir o ritmo e assistir a dança que, apesar de ser visual, pressupõe uma integridade e um desenrolar no tempo, deliciosamente violados pela representação fragmentária. Basta pensar em quadros como Femme en chemise assise dans un fauteuil de Pablo Picasso ou Woman with a mandolim de Gorges Braque, principais pintores do cubismo, para entender como a experiência do pós-guerra, do mundo fragmentado, se converteu em forma artística. Diferente da harmonia de diversas tradições anteriores da pintura, em que a iluminação da obra aponta para um foco, a experiência proposta pela obra vanguardista é outra. Ela não se organiza em torno de um centro, mas sim a partir da "trama do caos" de que fala Moraes. 
Guillaume Apollinaire, poeta francês lido por Girondo e seus contemporâneos, produziu uma poesia que também lançou mão da construção de imagens fragmentárias. O escritor, amigo de Picasso, faleceu no auge das vanguardas, em 1918, mas sua poética tornou-se paradigmática para os pósteros. É ele o dono do famoso verso (originalmente parte do caligrama Il pleut): "Il pleut des voix de femmes comme si elles étaient mortes même dans le souvenir", em um uso bastante interessante da imagem, muito similar ao que faria anos depois Girondo com o translado do imaterial ao campo visual que figura em diversos momentos de "Biarritz".

Neste sentido, portanto, podemos ler o fragmento na obra de Girondo como um vetor que aponta para dois lugares: para os caminhos e questões do erotismo e para as buscas radicais da vanguarda. Pode-se pensar que há uma espécie de filtro vanguardista no olhar para os corpos femininos. Na representação de personagens masculinos, impera a ironia pela composição desajustada ("Hombres con baberos de porcelana”). Muito diferente é o olhar para o feminino, em que há uma busca da condensação erótica em um único fragmento. Quando olhamos para a ilustração do poema “Plaza” (Imagem 2), podemos ver uma sugestão da consumação erótica pela continuidade dos corpos. Ainda assim, nesta cena que se encaminha para a supressão do abismo, podemos contrastar a representação masculina e feminina e ver as diferenças mencionadas claramente expostas.

Há na obra, como unidade, uma relação dialética, estabelecida com os pedaços. Esta poética do fragmento é carregada de luxúria em seus dois sentidos: material e sexual.

Diferente da grande tradição lírica, o interrogar do mundo por meio da subjetividade, em Girondo, não implica autofiguração. Não sabemos pelo seu discurso poético em que medida o eu-lírico dos poemas sofre o impacto que as outras personagens do cassino sofrem, dado o distanciamento irônico. Mas o ritmo eufórico de "Biarritz", mimese da velocidade com que o dinheiro transita pelo salão, deixa entrever que este sujeito está embebido, em alguma medida, no já mencionado aspecto polissêmico do luxo. É no olhar deslumbrado deste eulírico que se permite perder nas trilhas do erotismo sob a vertigem do moderno que vislumbramos o alcance e a historicidade desta poesia.

\section{DOS FESTEJOS E AGONIAS: ITINERÁRIOS DA VANGUARDA}

"Imaginária, a cidade de Girondo é uma espécie de utopia mecânica, é o território da maquinolatria e da simultaneidade" (PINTO, 2013, p. 125). A cidade, cenário e forma dos poemas de Girondo, é sustentada pelo embevecimento do eu-lírico. A crença na modernidade experenciada por Buenos Aires sustenta esta "utopia mecânica" de que fala Julio Pimentel

6 Também pode-se notar a influência da estética cubista no poema já citado de Oswald de Andrade, "Aperitivo" (Ver página 2), em que os flashes de realidade vão formando o espaço a partir das imagens. 
Pinto. O poeta argentino está do lado da vanguarda que, segundo Saúl Yurkievich, emerge "bajo el patrocinio de los tiempos modernos". Esta poesia empreendida pelo escritor argentino, com euforia similar à de Oswald e Mário de Andrade no Brasil, marca o desejo latino-americano de "integrarse al programa de la sociedad industrial" (YURKIEVICH, 1994, p. 94). Ajustado à efervescência vanguardista e aos seus desdobramentos formais, bem como ao estímulo da interdisciplinaridade, o escritor lança mão de técnicas que circulavam em Europa e, com maestria, experimenta algumas destas possibilidades formais em sua poética.

O fragmento, símbolo do mundo em ruínas do pós-guerra, é experimentado pelo autor paralelamente em sua poética e em seus desenhos. É por suas lentes que ele verá o "lugar sem limites" que a modernidade apresenta. O tom eufórico, por sua vez, é um eco do otimismo que atravessou a década de 1920 com o tímido aparecimento da industrialização.

Tomando quase um século de distância, sabemos que este otimismo não teve vida longa. Com a quebra de bolsa de Nova York, em 1929, a euforia do moderno estava deslocada. É quando a felicidade que anda a pé, do poema de Oswald, se converte no verso drummondiano: "Perdi o bonde e a esperança". A cidade-prosperidade dá lugar a um espaço fantasmagórico e agônico em Pablo Neruda, ao concluir: “iqué ciudades opacas recorremos!” e em César Vallejo ao subverter os signos louvados na década anterior: "Crece la desdichada, hermanos hombres, / más pronto que la máquina, a diez máquinas, y crece”. Os ritmos do moderno serão cantados em sua contraface, reduzindo drasticamente o espaço para exaltação. O mundo agora volta a ser visto por boa parte destes poetas como a pesada tampa de um certo Spleen.

Mas, mesmo distanciados dos bons ventos do otimismo, a poesia de Girondo segue pulsante a cada nova leitura. Isso deve-se ao modo como o autor converte este otimismo em forma literária e lança um olhar maliciosamente caótico para os estilhaços do mundo que se travestiam de integridade. As cidades podem cair em decadência e as promessas de modernidade podem ser desditas, mas o olhar girondiano segue, no marco de sua poética, triunfante. Os 20 poemas para ser leídos en el tranvía são um convite para voltar a ver o mundo pelas lentes da luxúria vanguardista.

\section{Referências bibliográficas}

ANDRADE, Oswald de. Obras completas. Rio de Janeiro: Civilização Brasileira, 1971.

ANDRADE, Carlos Drummond de. Nova reunião: 23 livros de poesia. São Paulo: Companhia das Letras, 2015.

APOLLINAIRE, Guillaume. Calligrammes, poèmes de la paix et de la guerre. Paris: Gallimard, 1966.

BATAILLE, George. O erotismo. tradução de Antonio Carlos Viana. Porto Alegre : L\&PM, 1987. 
BAUDELAIRE, Charles. Les fleurs du mal. Paris: Flammarion 1991.

BORGES, Jorge Luís. "El escritor argentino y la tradición". In: Obras Completas. Buenos Aires: Emecé Editores, 1974. p. 267-274.

CANDIDO, Antonio. “Literatura e cultura 1900-1945”. In: Literatura e sociedade. Rio de Janeiro: Ouro sobre o azul, 2014. p. 117-145.

FREUD, Sigmund. Obras completas. Volumen 23 (1937-39). Traducción de José Luis Etcheverry. Amorrortu editores, 1991.

GIRONDO, Oliverio. 20 poemas para ler no bonde. São Paulo: Editora 34, 2014. et al. "Manifiesto Martín Fierro". Revista Martín Fierro, Buenos Aires, 15 de maio de 1924, pp. 1-2.

HUGO, Victor. Euvres complètes de Victor Hugo. En voyage, tome II. Paris: Librairie Ollendorff, 1910.

MONTALDO, Graciela. La sensibilidad amenaza. Fin de siglo y Modernismo. Rosario: Beatriz Verbo Editora, 1994.

MORAES, Eliane Robert. O corpo impossível. São Paulo: FAPESP/Iluminuras, 2002.

MULLER-BERGH, Klaus. El hombre y la técnica: contribución al conocimiento de corrientes vanguardistas hispanoamericanas In: Revista Iberoamericana, v. 48, p. 149-176, 1982.

NERUDA, Pablo, Residencia en la tierra 1 (1925-1931). Buenos Aires: Losada, 1966

OSORIO, Nelson. Para una caracterización histórica del vanguardismo hispanoamericano In: Revista Iberoamericana, v. 47, p. 227-254, 1982.

PINTO, Julio Pimentel. Ruas de Borges e de seus contemporâneos In: História (São Paulo), v. 22-2, p. 121-132, 2003.

SCHWARTZ, Jorge. Vanguardas latino-americanas. Polêmicas, Manifestos e textos críticos. São Paulo: Edusp, 2008.

SCHWARZ, Roberto. "A carroça, o bonde e o poeta modernista”. In: Que horas são? São Paulo: Companhia das Letras, 1989. p. 11-28.

SIMON, Iumna. Orelha do Livro. In: BÜRGER, Peter. Teoria da vanguarda. São Paulo: Cosac Naify, 2008.

VALLEJO, Cesar. Obra poética completa. Madrid: Alianza Tres, 1986.

YURKIEVICH, Saúl. “Los signos vanguardistas: el registro de la modernidad”. In: PIZARRO, Ana (Org.) Palavra, Literatura e Cultura. São Paulo: Memorial, UNICAMP, 1995. 89-98. 